\title{
A Sociological Study of the Homicide in Sri Lanka: A Case Study in Rathnapura Secretariat Division
}

\author{
N.S. Jayathunga
}

Department of Social Sciences, Faculty of Socail Sciences and Languages, Sabaragamuwa University of Sri Lanka,P.O Box 02, Belihuloya.amisara@sab.ac.lk

\begin{abstract}
This study is an attempt to recognize the causes for homicide and analysis them in a sociological aspect. The crimes which are differed to each society has a big impact on contravention of the collective conscious that helps to positive existence the in the society. As well as this social revolution process copes with the globalization process. The crimes such as murders, rape, child abuse, hitting, robbery and illegal money printing have been expanding in Sri Lankan society with the current wave of crime. Crimes are the major criterion of determining development in each country. This study seeks to identify the reasons and the remedies for the murders in Sri Lanka. Rathnapura police division was selected for the study because of several reasons. It is one of the districts, which recorded the highest number of crimes, and it mainly represents the crimes in rural sector. Non-probability purposive sampling used for the study because the area is much specified and is not very common scenario for each household. 20 cases of murders were included in the sample. The sample is derived through the secondary source of police reports taken from the police head quarters; research papers, publications and web sites were used as the secondary data. Structural and non-structural interviews and observations are further used. There are several limitations of the study. Although crime is a widespread issue, all areas in Sri Lanka were not covered through the study due to time and budgetary constraints. Because Rathnapura district records the very high rate of crimes, the study selected the particular district but Rathnapura police division is the only concern of the study as to make the study easier and descriptive. The study is only based on the cases from 2001 upto2002. Major limitation of the study is that the concealing the real information about the particular incident by the victims and criminals because of several sociological and legal obstacles. The study concludes that the major causes for murders in Rathnapura police division as informal sexual relations, alcoholism, poverty, illiteracy, family background, revenging purposes, monitory purposes, environment and hot temper. Some short, medium, and long-term suggestions are proposed by the study to minimize murders as a one of the crimes in Rathnapura police division as a final contribution of the study.
\end{abstract}

Key words: Crime, Homicide, Social problem 


\section{Introduction}

The wave of crimes has been rapidly increasing in Sri Lanka as a key social problem and it is developing as a result of the rising of the population and the intelligence of the modern technology than the earlier. The crimes which are differed to each society has a big impact on contravention of the collective conscious that helps to positive existence the in the society. As well as this social revolution process copes with the globalization process. The crimes such as murder, rape, child abuse, hitting, robbery and illegal money printing have been expanding in Sri Lankan society with the current wave of crime. Crimes are the major criterion of determining development in each country. Only homicide is concerned by this study because it is directly influenced to the people. Homicides are increased at present rapidly than the earlier because of the complexity and the competition of the society. Due to this condition, the large numbers of harms have spared out to the people all over the country. Fear of the people, suspicions, threats, revenging, suicides are the several consequences of the homicide and this topic was selected to seek the causes of homicide in Sri Lanka in sociological aspect.

\section{Literature}

Homicide is the one of the significant impact of the human beings considering the other types of Crimes of Sri Lanka. It can be explained simply as "the unlawful killing of a human being with malice aforethought" (Kornblum and Julian, 1974). According to the Encyclopedia of Americana homicide explains, "Assassinate a person with purposively is a homicide" (The Encyclopedia Americana, 1959). It means someone is killing a person must be positively with the feeling of assassination otherwise it may happened accidentally is not consider as a homicide. Mainly Homicide can be classified in to two ways as Lawful Homicide and Unlawful Homicide (Grero, 1988). Lawful Homicide can be divided into two ways again as Justifiable homicide and Excusable Homicide. According to reference, "The psychological of crime" murder has been classified in to two ways as symptomatic murder and manifest murder (Abrahamsen, 1960). Mainly the criminals related to symptomatic murder, their internal divergence coming from the inner part of the mind since their childhood is the consequence to this type of crime and it is taken place unconsciously. Sexual drives and aggression drives including Frustration and sexual jealousy directly influenced to this type of murder cases. Mostly the manifest criminals are making out the general crimes of the society coping with the community and make the erroneous against to society is significant. 
Homicide can be recognized as an inhuman action which has been taken place by different levels in different societies in the world. Especially some countries believed that assassination of the parents as one of the customs. However the purpose of assassination and the way of assassination may be differed from country to country can be reflected on as a homicide. Jayewardene and Ranasinghe (1963) have mentioned some examples for homicide as assassination, sudden homicide, killing someone by expecting the self protection and caring property, suicide, the death caused by war, slaughtering people according to general law of the country, killing prisoners by escaping, assassination the politicians and killing the enemies of the war" (Jayewardene and Ranasinghe, 1963). The one of the greatest research related to crime in Sri Lanka done by Wood (1961) has found stressful or frustrating, are proposed as the basis for high rates of homicide. The national survey was based on a questionnaire completed by local police officials for 577 persons officially charged with murder or attempted murder and, 457 homicide and attempted homicide victims during specified months 1956 and 1957. He used samples of the village studies was based on interviews with males aged 17 and over who had committed "grave" crimes against persons or property during the previous five years. According to this study the greatest frequency of homicide in Ceylon lies in the "rurban" villages of the maritime area. This is specially the area where landlessness, excessive demand for nonagricultural employment and the non traditional role of subordinate status for the Goigama caste have had greatest impact. The empirical data showed that murders in this area have experienced these changes most keenly and manifest reaction of severe alienation with complaints of harassement (Wood, 1961). The one of the criminological research revealed mostly Americans were used the guns as the main technique for the assassinations by representing $60 \%$. The majority of men were the victims of the homicide done by unknown people representing $75 \%$. Generally murder cases were taken place at the weekends, at night, inside the home and the offenders were with the alcohol or drugs were the few factors found by this research (Gottfredson and Hirschi, 1990). Sociological Theory, Psychological Theory, Biological Theory, Ecological Theory, Labeling Theory and Anomic Theory were further used to comprehend the criminal behavior of the Homicide for this study.

\section{Research Problem of the study}

What are the causes of Homicide?

Related to the above research problem, recognition of the causes of homicide in Sri Lanka is a major rationale of this study. Introducing reasons of homicide is one of the enormous duties of the sociologist and it helps out to obtain the possible solutions to diminish the crime in related area as a proper way. 
The main objective of this Study was recognition of the causes of Homicide in Sri Lanka. Understand the ethnicity, age group, civil status, educational level and family back ground of the criminals, understand the methods which criminals used for homicide, understand the nature of the relationship with the community of the criminals, recognition the attitudes towards the law of the criminals and suggest the possible solutions for Homicide were the other specific objectives of this research.

\section{Methodology}

Non-probability purposive sampling used for the study because the area is much specified and is not very common scenario for each household. 20 cases of homicides were included in the sample because of this circumstance was a social deviant behavior differed than the other social behaviors of the human beings. The sample is derived through the secondary source of police reports taken from the Annual Reports of the I.G.P. Administration, Encyclopedias, Dictionaries, magazines, Census related to the homicide were used as the secondary data and Structural and Non structural interviews, Case Studies and Observations were further used as the primary data.

This study mainly expected to make out the causes of homicide related to one of the grave crimes. This study was selected only the Rathnapura police division which included 15 police divisions because of several reasons. It is one of the divisions which recorded the highest number of crimes and it has an increasing trend of crime mainly represents the crimes in rural sector.

\section{Background Details of Criminals}

This study found the ethnicity, age structure, civil status, educational level, employment, and family background of the criminals as the background details of the homicide in Rathnapura police division. Consideration of the ethnicity majority of the Sinhalese represented $80 \%$ as the high quantity concerned with the homicide and 20\% Tamil was less represented. It shows the following Table 1.

Table 1: Ethnicity of the criminals

\begin{tabular}{|c|c|c|}
\hline $\begin{array}{c}\text { Characteristics } \\
\text { Ethnicity }\end{array}$ & No & \% \\
\hline Sinhalese & 16 & 80 \\
\hline Tamil & 04 & 20 \\
\hline
\end{tabular}

Source- Field Data

According to Table 2 categorizing of the age structure in systematically $30 \%$ represented in a 31-40 age group in view of high amount deal with the 
homicides, $25 \%$ represented the $20-30$ age group and $15 \%$ represented the 61-70 age group and equally $10 \%$ for $41-50$ and $10 \%$ for $51-60$ age group.

Table 2: Age Structure of the criminals

\begin{tabular}{|c|c|c|}
\hline $\begin{array}{c}\text { Characteristics } \\
\text { Age Structure }\end{array}$ & No & \% \\
\hline $20-30$ & 05 & 25 \\
\hline $\mathbf{3 1 - 4 0}$ & $\mathbf{0 6}$ & $\mathbf{3 0}$ \\
\hline $41-50$ & 02 & 10 \\
\hline $51-60$ & 02 & 10 \\
\hline $61-70$ & 03 & 15 \\
\hline $71-80$ & 02 & 10 \\
\hline
\end{tabular}

Source- Field Data

The study revealed the civil status of the criminals representing $70 \%$ of married people, as the best part of the research and unmarried were $30 \%$ (Table 3).

Table 3: Civil Status of the criminals

\begin{tabular}{|c|c|c|}
\hline $\begin{array}{c}\text { Characteristics } \\
\text { Civil Status }\end{array}$ & No & \% \\
\hline Married & 14 & 70 \\
\hline Unmarried & 06 & 30 \\
\hline
\end{tabular}

Source- Field Data

Deliberation of the educational level of the homicide criminals in this study can be categorized in descending order as never school $40 \%$, up to year five $35 \%$ and year $6-8,25 \%$. Never schooling is the significant factor related to the study. The people could not be realized the seriousness about the nature of the homicide because of their poor education (Table 4).

Table 4: Educational Level of the criminals

\begin{tabular}{|c|c|c|}
\hline $\begin{array}{c}\text { Characteristics } \\
\text { Educational Level }\end{array}$ & No & \% \\
\hline Never Schooling & 08 & 40 \\
\hline Up to year 5 & 07 & 35 \\
\hline Year 6-8 & 05 & 25 \\
\hline
\end{tabular}

Source- Field Data

Employments of the Criminals of this study were as the descending order representing 35\% for Labors, 20\% for Vegetables and fruits Sellers, equally representing $15 \%$ for Masons, mining, and Unemployed Persons. Majority of the people who connected with the homicide were less earners based on 
their educational level. Family background of the criminals can be shown as the following Table 5.

Table 5: Family Background Details of Criminals

\begin{tabular}{|l|c|c|}
\hline Family Members & No & $\%$ \\
\hline Parents, Relatives and Children & 5 & 25 \\
\hline Father, Step Mother and Children & 3 & 15 \\
\hline Mother, Step Father and Children & 3 & 15 \\
\hline Only the Mother and Children & 4 & 20 \\
\hline Husband, Wife and Children & 2 & 10 \\
\hline Husband and Wife Only & 6 & 30 \\
\hline
\end{tabular}

Source- Field Data

Highlighted persons of the table were criminals of the Homicide. This study identified the children who were with their parents and relatives (Extended Family) and only husband and wife family implicated with the murder cases contributing as a large proportion was representing $25 \%$ and $30 \%$ but less significant number for the husband, wife and children family type (Nuclear Family) contributing to the homicide.

Main purpose of this study was making out the causes link with the homicide in Rathnapura police division. According to this research mainly it was recognized the causes as informal sexual relations representing $30 \%$ as the big impact, revenging purposes representing 20\%, high temper representing $20 \%$, drunkenness representing $15 \%$, mining industry representing $10 \%$ and rapes representing $5 \%$. These causes can be summarized according to the following Table 6 .

Table 6: Causes for Homicide

\begin{tabular}{|l|l|l|}
\hline Reasons & No & \% \\
\hline Illegal sexual affairs & 06 & 30 \\
\hline Revenging purposes & 04 & 20 \\
\hline High temper & 04 & 20 \\
\hline Drunkenness & 03 & 15 \\
\hline Mining industry & 02 & 10 \\
\hline Rapes & 01 & 05 \\
\hline Total & $\mathbf{2 0}$ & $\mathbf{1 0 0}$ \\
\hline
\end{tabular}

Source- Field Data 
Consideration of the illegal sexual relation as the main reason of this studies it was mainly based on the sexual jealousy of people. Especially the relationships made by the father in law with daughter in law, by wife with husband's own brother, by husband with his mother in law were the largest part of the illegal sexual relations they made. Generally after getting married people making an additional affair instead of their own marriage were directly caused to the homicide based on the sexual jealously.

Revenging purpose representing $20 \%$ was as the second key reason of this study and it was a one of the results of the long-term process. Memorization the older annoyance, after getting the victory of the land dispute and frustration of the love affair were several minor reasons link with the revenging purpose.

Third reason, high temper also link with the revenging purpose but it was a short-term issue. According to this condition, killed a driver result of the seeing knocking at the vehicle of his one of the neighbors on the road, husband killed his wife using the stick based on the family dispute; father killed his own son result of the high temper could be found through this study.

Drunkenness representing $15 \%$ was directly influenced to the homicide as a key factor in this study area. Majority of the criminals involved with the crimes using alcoholism. Generally taking alcohol is directly influenced to assassinate the people, rape the women, for child abuse and any type of dispute people made because of avoiding the inconvenience of the matter (Figure: 1).

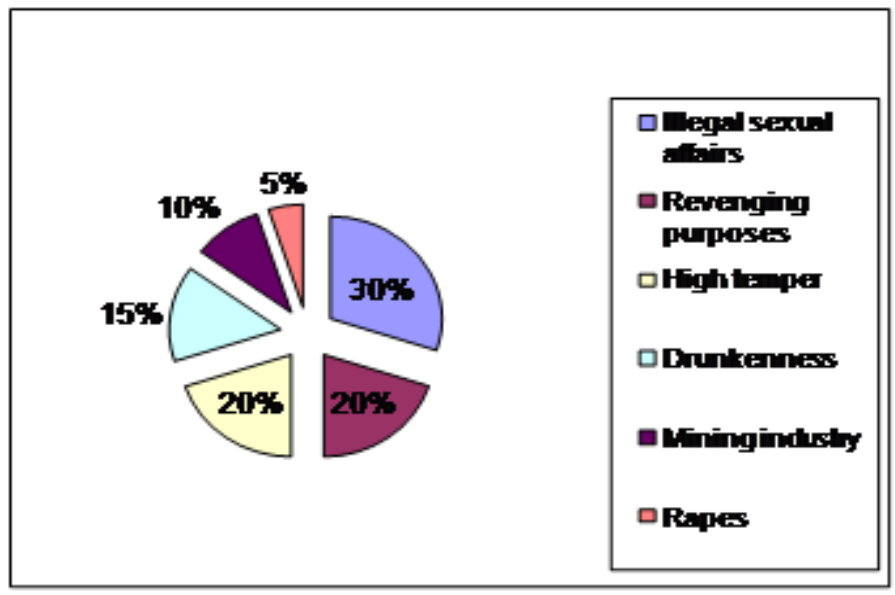

Figure 1: Causes for homicide

Source- Field Data

Mining industry representing 10\% was another key factor to the homicide found by this research and this industry is a very familiar and heritage to this 
area. Stealing the gem, quarrelling for gem and swollen the gem were identified matters dealing with the mining were directly caused to homicide.

This study found the rape as a major cause for the homicide and especially there was a inter relationship ensued among the drunkenness, rape and assassination. Murder was the final alternative of the rape case by the criminals used.

Hitting on the head by using stick representing $35 \%$, hitting on the head by using weapon representing $25 \%$, snubbing representing $20 \%$, strangling the neck representing $15 \%$ and hitting by using the axe were the methods identified through this study. Assassination techniques can be showed as the Figure 2.

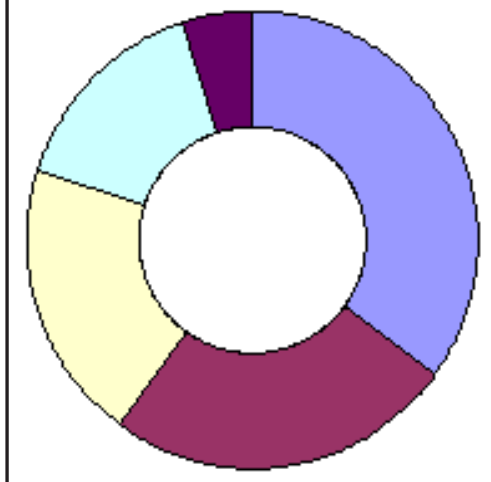

$\square$ hitting on the head by using stick

$\square$ hitting on the head by using

weapon

$\square$ snubbing

$\square$ strangling

口using axe

Figure 2: The ways of homicide

Hitting on the head by using stick was the key technique of contributing the large extent and the smaller amount usage was the hitting by using the axe of this study.

The relationship between homicide and victimized was a significant aspect of this research. According to this relationship mainly people who assassinated the people were unknown the high representation of this study. Other offences were in orderly as neighbors, son, father, friend, husband and wife. Following Figure 3 shows the summary of the above relationships.

Large amount of the people being unknown who involved with the murder cases was the significant factor, which may be the contract for determining the financial require. But less percentage of wife and husband were impact to the homicide was a different significant of this study. The Table shows the relationship between homicides and victimized. 


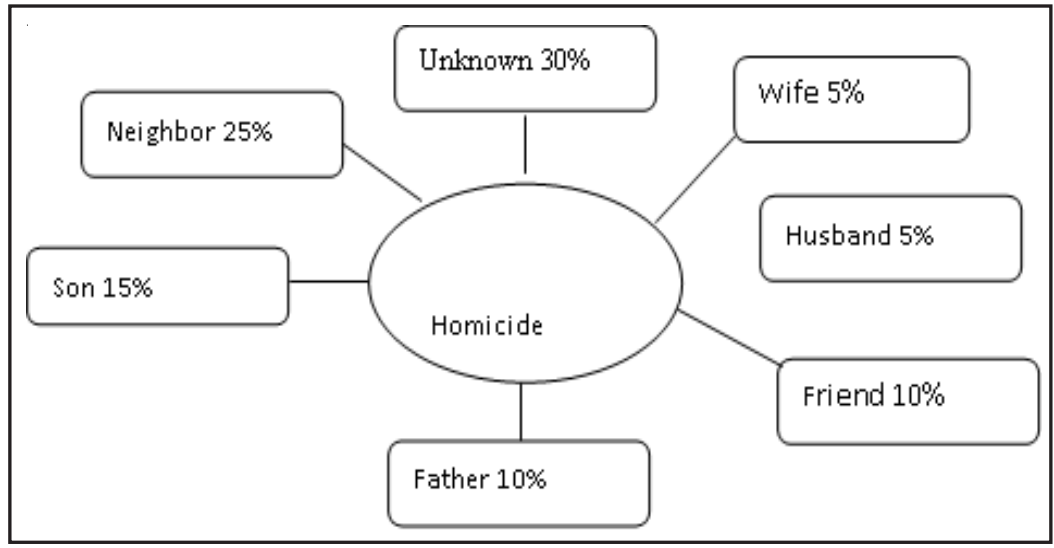

Figure 3: The relationships between homicide and victims

Source-Field data

This study analyzed the nature of the relationships of the criminals by determine to identify the integration they had with the community. Following Table 7 shows the nature of their relations.

Table 7: The nature of the social relationships of the criminals

\begin{tabular}{|l|c|c|}
\hline $\begin{array}{l}\text { The nature of the social } \\
\text { relations }\end{array}$ & No & \% \\
\hline Close relationships & 09 & 45 \\
\hline General relationships & 06 & 30 \\
\hline Relationships with deviants & 03 & 15 \\
\hline Less relationships & 02 & 10 \\
\hline Total & $\mathbf{2 0}$ & $\mathbf{1 0 0}$ \\
\hline
\end{tabular}

General view of the criminals in the society is if they are involving with crimes they associate and build up the relations directly with the deviants related to any type of crimes in the society based on the socialization through the peers. But consideration of this study it revealed that majority of criminals had very close relationships with their neighbors, relations and friends representing $45 \%$ than the less relations with the deviants representing $15 \%$.

The attitudes towards the law of the Criminals of the homicide are significant of this study as ignoring the law due to high temper, revenging purposes by ignoring law, hiding to the law and engaging with the faults by knowing the law. Following Table 8 shows how criminals dealt with the law and their feeling towards the law. 
Table : 8 The attitudes towards the law of the Criminals

\begin{tabular}{|l|l|l|}
\hline Attitudes tow ards the law & No & \% \\
\hline Ignoring the law due to high temper & 07 & $\mathbf{3 5}$ \\
\hline Revenging purposes by ignoring law & 06 & 30 \\
\hline Hiding to the law & 04 & 20 \\
\hline $\begin{array}{l}\text { Engaging with the faults by knowing the } \\
\text { law }\end{array}$ & 03 & 15 \\
\hline Total & $\mathbf{2 0}$ & $\mathbf{1 0 0}$ \\
\hline
\end{tabular}

This study found the majority of the criminals that ignored the law because of the high temper representing 35\% of the total. Even though Majority of the criminals had the views about the law of the country but they did not consider the law because of giving priority for high temper. Above factors mainly influenced to the homicide in Rathnapura police division. There are large number of secondary results were created based on murder because it is directly influenced to the people against to the humanity. Decreasing the social integration, disorganizing the social structure, contravention the customs, values and norms, back warding the development of the country, increasing the fear to survival, increasing accidents, rising the family problems, developing deviant behaviors, disregard the responsibilities are the few circumstances created from the increasing homicide in the country. This can be considered as a major social problem because this condition directly and indirectly inclined to the entire society very destructively.

\section{Conclusion}

Rathnapura Police division was the selected study area because of the increasing trend of crimes could be identified and it was one of the highest crimes recorded area among the other districts in Sri Lanka according to police reports. Majority of the criminals related to homicide were uneducated and very distant from the urban cities. Majority of criminals were employed with the minor occupations and they had the low economical condition result of the poor education. As the main purpose of this study, recognized the several major causes related to homicide. Informal sexual relations, revenging purposes, unexpected anger, drunkenness, mining industry and rape were the significant reasons recognized through this study. Informal sexual relations were the most indispensable reason caused to homicide based on the sexual jealousy in a psychological aspect. And the rape was a low representation rate attach to the homicide result of the breaking the ways revealing information to another was assassination. Criminals had very close relations with their community before they involved with the crimes. Even if the society is changed by the modernization, the modern techniques were not used for murders in rural areas. And most of them were with the general views of 
the law in the country but they ignored them because of the high temper coming forward. According to the above conclusion can be mentioned few recommendations to get rid of the homicide in the society with the result of the micro level research applying to the whole. There should be immediate legal judgment incorporate to crimes, there should be impartially of the law, Establishment of counseling centers at rural level to minimize the family related problems, severe and minor criminals should be separately rehabilitated, and sexual relation education should be included at school level to reduce the curiosity of sex

\section{References}

Abrahamsen, D. (1960) The Psychology of Crime, Science edition, New York.

Grero, C.A. (1988) Culpable Homicide Proof and Defences, C, Ananda Grero,Singha Printers, Telijjawila.

Gottfredson, M.R. and Hirschi, T. (1990 ) A General Theory of Crime, Stanford University Press, U.S.A.

Jayewardene, C.H.S. and Ranasinghe, H. (1963) Criminal Homicide in the Southern Province, The Colombo Apothecaries Co. Ltd,Colombo.

Kornblum, W. and Julian, J. (1974) Social problem ( $7^{\text {th }}$ edition), PrenticeHall Inc, USA.

Wood, A.L. (1961) "A Socio- structural analysis of murder,suicide, and economic crime in Ceylon”, American Sociological Review, v. 26.

The Encyclopedia Americana, (1959) Americana Coorporation, U.S.A. 